\title{
Darryl Francis and the Making of Monetary Policy, 1966-1975
}

\section{R. W. Hafer and David C. Wheelock}

T oday, it is widely acknowledged that the fundamental mission of monetary policy is to maintain the long-run stability of the price level. Economists and policymakers generally agree that persistent changes in the price level (inflation and deflation) are, in the long run, caused by growth of the money stock in excess of the growth of total output. It is thought, moreover, that monetary policy can best promote high employment and maximum sustainable economic growth by maintaining reasonable stability of the price level. The charter of the European Central Bank, as well as legislation governing the behavior of central banks in several countries, specifies price stability as the sole objective for monetary policy. The Federal Reserve, by contrast, is assigned multiple policy objectives-"maximum employment, stable prices, and moderate long-term interest rates" (Federal Reserve Reform Act of 1977). Nevertheless, in recent years U.S. monetary policy has been consistent with a gradual reduction in the rate of inflation to the point where many economists believe that price level stability, for practical purposes, has been achieved.

The consensus about the importance of price level stability and the role of monetary policy is a fairly recent development. The macroeconomic paradigm that emerged from the Great Depression and dominated from the 1940s to about 1980 held that full employment should be the primary objective of monetary and fiscal policy. Stabilization policy was viewed as choosing from among a menu of unemployment and inflation rates along a stable Phillips curve. Many economists and policymakers viewed moderate inflation as an acceptable cost of maintaining full employment. During the 1950s the Federal Reserve frequently was criticized for

R. W. Hafer is a professor and chairman of the Department of Economics and Finance at Southern Illinois University at Edwardsville. David C. Wheelock is an assistant vice president and economist at the Federal Reserve Bank of St. Louis. The authors thank Ted Balbach, Michael Bordo, Bob Hetzel, Garret Jones, Thomas Mayer, Allan Meltzer, Bill Poole, Bob Rasche, and Anna Schwartz for their comments. Heidi L. Beyer provided research assistance.

(C) 2003, The Federal Reserve Bank of St. Louis. paying "excessive" attention to inflation, to the detriment of employment and output growth.

Perhaps in part a response to such criticism, in the early 1960s the Fed's monetary policy generally became more expansionary. Inflation began to rise in 1965 and continued to increase through the 1970s. Unemployment fell at first, but during the 1970s the average rate of unemployment was higher than it had been during the preceding two decades. Moreover, inflation, unemployment, and real output growth all became more variable as the average rate of inflation increased.

Not surprisingly, the poor performance of the macroeconomy during the 1970s brought the Federal Reserve much criticism. Among professional economists, once-dominant views about the roles of monetary and fiscal policy began to shift. Experience demonstrated the folly of those policies designed to exploit a tradeoff between unemployment and inflation and showed that expansionary monetary policy could not permanently lower the unemployment rate or increase the growth rate of real output. By October 1979, when Federal Reserve officials finally resolved to bring inflation under control, the costs of disinflating were substantially higher than they would have been earlier in the decade when inflation was lower and less entrenched.

This paper examines alternative views about monetary policy within the Federal Reserve System from the mid-1960s to the mid-1970s. We highlight the views of Darryl Francis, president of the Federal Reserve Bank of St. Louis from 1966 to 1975. In contrast to most of his Fed colleagues, Francis argued that monetary policy should concentrate on halting inflation. He believed that the influence of monetary policy on the unemployment rate was unpredictable and at best temporary. He was an early proponent of the view that the unemployment rate (and real output growth) tends toward a "natural" rate determined by factors outside the control of monetary policymakers. Francis argued that the Fed should maintain a steady growth rate of the money stock and blamed the Fed's targeting of interest rates and money market conditions for producing destabilizing swings in money stock growth. 


\section{Figure 1}

\section{Inflation Rate}

Quarterly Data, Consumer Price Index, 1951-82

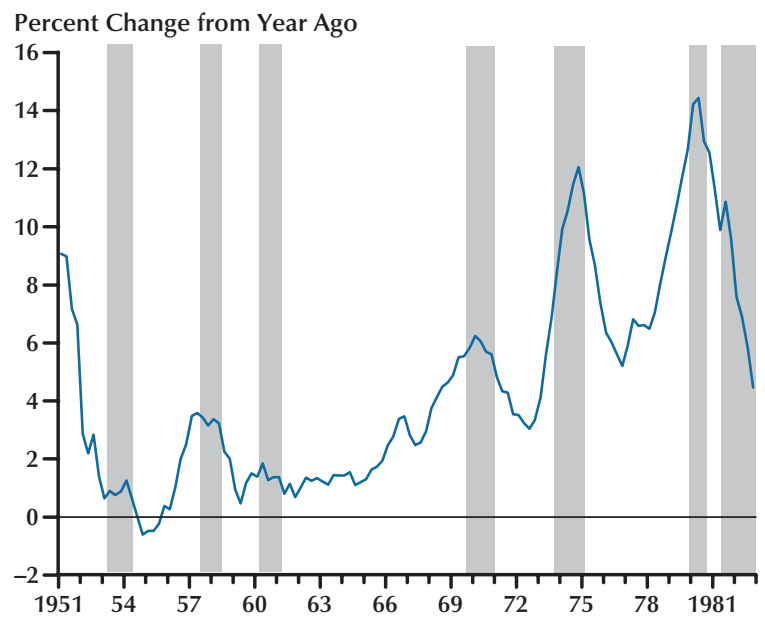

NOTE: Shaded bars represent recessions.

Darryl Francis's death in early 2002 prompted this historical account of his policy views and the debates within the Fed when he was president of the St. Louis Bank. ${ }^{1}$ Reviewing the economic events and debates of this period not only provides a better understanding of the reasons behind the Fed's monetary policy actions, but also illuminates how policy views within the System evolved toward recognizing price level stability as the principal long-run objective for monetary policy.

The next two sections set the stage for our review of Francis's policy positions. First we summarize macroeconomic conditions from the 1950 s through the 1970s, and then we describe the development of monetary policy from 1951 to 1966, when Francis became president of the St. Louis Fed. The subsequent section describes Francis's views about key policy issues by drawing extensively on his speeches and remarks at Federal Open Market Committee (FOMC) meetings. We highlight differences between the views of Francis and the consensus of his FOMC colleagues.

\section{MACROECONOMIC OVERVIEW}

In March 1951, the Federal Reserve and U.S. Treasury reached an agreement (the "Accord") that

1 We focus on Francis's professional contributions. For more personal reflections, see Poole $(2001,2002)$ and Jordan (2001)

\section{Figure 2}

\section{Unemployment Rate}

Quarterly Data, 1951-82

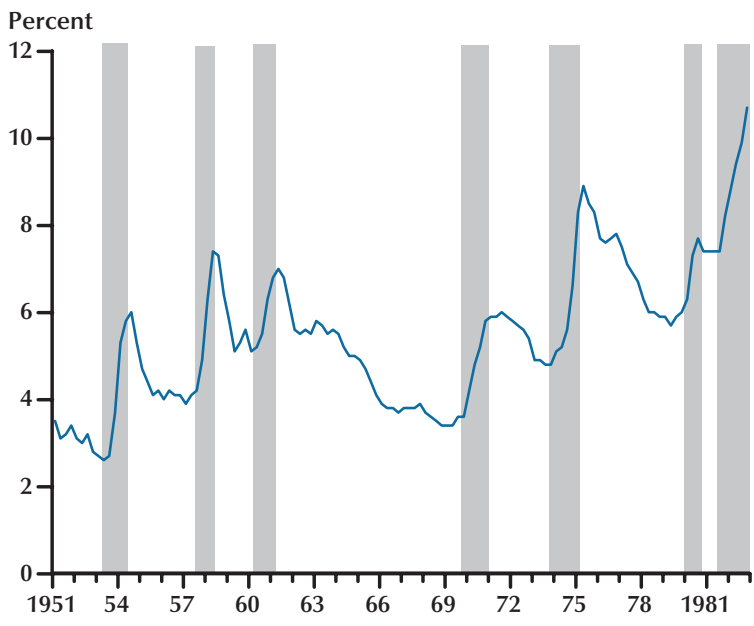

NOTE: Shaded bars represent recessions.

freed the Fed from an obligation to maintain specific yield ceilings on U.S. government securities. The agreement was sparked by a sharp increase in the rate of inflation in 1950 and early 1951 and the desire of Fed officials to halt the rise by limiting the growth of bank reserves and the money stock. Under the Accord the Fed agreed to continue to support the government securities market temporarily when the Treasury issued new debt, but yields were permitted to find their market levels as the Fed directed its focus toward containing inflation.

Inflation declined sharply in 1952 and remained low until 1956, as Figure 1 shows. After reaching an annual rate of nearly 4 percent in 1957, inflation declined to under 2 percent and remained remarkably steady until 1965. The rate of inflation then began to move upward in successive waves, with peaks in 1970, 1974, and 1980. Each peak came during a recession and followed deliberate actions by the Federal Reserve to tighten policy. In each successive cycle, however, the inflation nadir and subsequent peak were higher than those associated with the previous cycle. In 1980 the consumer price index increased at a 13.5 percent annual rate, its highest annual rate since 1947 when wartime price controls had just been lifted.

We plot the unemployment rate over the same years in Figure 2. The unemployment rate fluctuated considerably during the 1950 s, then fell almost 


\section{Figure 3}

\section{Phillips Curve}

Annual Average of Quarterly Data, 1960-82

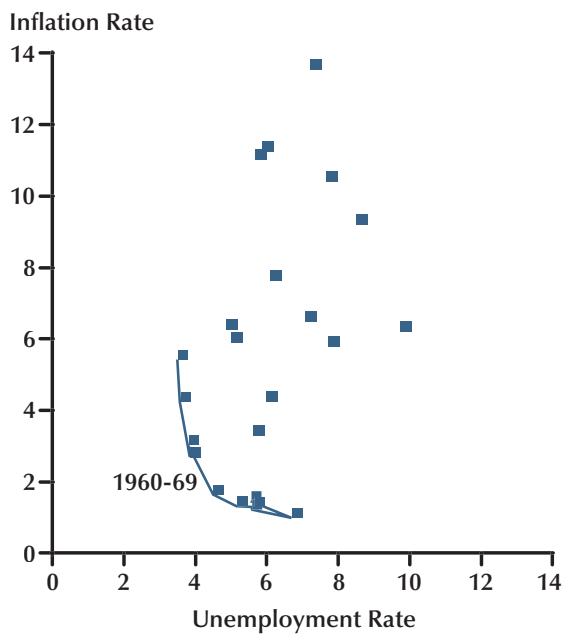

continuously from 1963 to 1969 to end the decade below 4 percent. Much of the decline came as inflation was rising, suggesting that Federal Reserve officials had revised their preferences in favor of a lower unemployment rate and were willing to accept higher inflation as the cost of pushing the unemployment rate down.

The unemployment rate did not continue to fall during the 1970s, even though inflation continued to rise. As Figure 2 shows, the unemployment rate increased sharply during the recession of 1970; though it declined during the subsequent recovery, it did not fall below 5 percent. Another recession in 1974-75 pushed the unemployment rate above 8 percent. In the subsequent recovery, the rate again fell to a low point that was higher than that of the previous expansion. Finally, during the 1981-82 recession the unemployment rate peaked at over 10 percent-its highest level since the Great Depression.

Although short-run peaks in the unemployment rate tended to occur when the inflation rate was falling, the negative correlation between annual rates of unemployment and inflation that characterized the 1960s was absent during the 1970s and early 1980s. As shown in Figure 3, unemployment and inflation rates appear to have followed a predictable Phillips curve pattern - higher unemployment rates associated with lower inflation-during the 1960s. From 1970 to 1982, however, the correlation between unemployment and inflation rates

\section{Figure 4}

\section{Inflation Rate and M1 Growth}

Quarterly Data, 1951-82

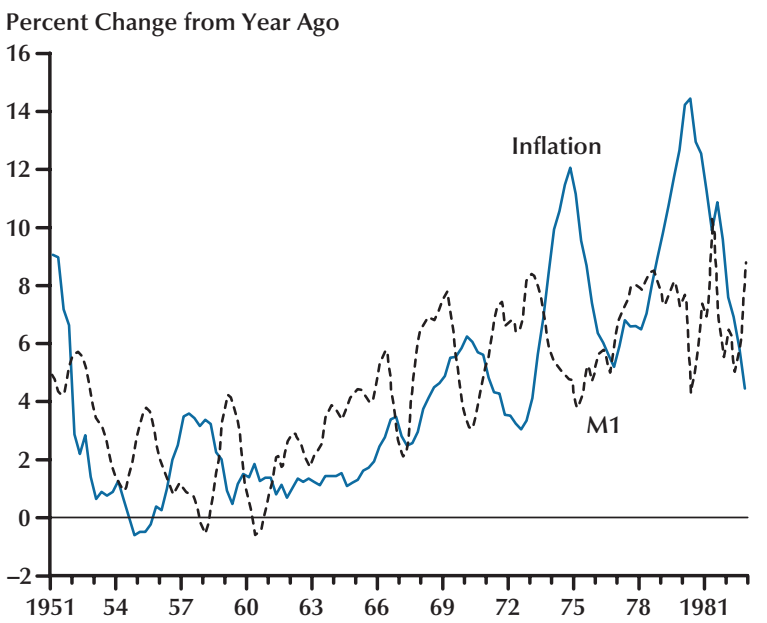

was low. Moreover, both rates followed upward trends over the period, which ran counter to a view commonly held during the 1960s that expansionary monetary policy could permanently lower the average rate of unemployment. ${ }^{2}$

It is beyond the scope of this paper to identify the sources of specific changes in inflation or unemployment during the 1960s and 1970s. Oil price shocks in 1973 and 1979 and other supplyside disturbances are often blamed for much of the adverse movements in unemployment and the price level during the 1970s. ${ }^{3}$ The increasing trend rate of inflation is today widely attributed to a rising average growth rate of the money stock. The association between money stock growth and inflation is illustrated in Figure 4, where we plot the growth rate of $\mathrm{M} 1$, a narrow monetary aggregate, alongside the inflation rate. ${ }^{4}$ The figure illustrates that money growth and inflation moved inversely in the short run, reflecting the Fed's attempts to tighten policy in response to higher inflation. Over the longer term, however, the upward trend in the rate of inflation was associated with a similar trend in money stock

\footnotetext{
2 Hafer and Wheelock (2001) provide a summary of alternative views during the 1960 s about the association between inflation and unemployment in the long run.

3 See Barsky and Kilian (2001) for an alternative view.

4 We plot M1 growth because it was the aggregate favored by Darryl Francis and Federal Reserve Bank of St. Louis staff. M2 growth behaved similarly, however, during the period illustrated here.
} 
growth. Like inflation and unemployment, M1 growth rose and fell in waves, with both growth rate peaks and troughs as high or higher than those of the previous cycle.

\section{MONETARY POLICY FROM THE ACCORD TO 1966}

We assert that neither the trend nor the variability of money stock growth, inflation, or the unemployment rate during the late 1960s and the 1970s reflected a well-designed monetary policy. To provide some information on how policy decisions were made during these years, we briefly review economic policy developments in the period preceding the "Great Inflation" of 1966-80.

During the 1950s, monetary policy focused largely on the threat of inflation. Inflation fell sharply in 1952 when the Fed began to exercise its new independence. Following the 1953-54 recession, however, inflation seemed poised to increase again. Federal Reserve Chairman William McChesney Martin vowed not to repeat the mistake of the previous expansion, when interest rates were not increased fast enough to curb inflation. Consequently, the Fed tightened policy in 1956 and maintained its stance even as economic activity began to slow. Although a few FOMC members called for an easier policy, the majority thought that continued restraint was needed to avoid "sloppy" financial markets and to contain inflationary momentum. ${ }^{5}$

The Fed's concern about potential inflationary momentum was heightened in 1957 when, contrary to widespread expectations, the price level failed to decline as economic activity began to slow. ${ }^{6}$ The Fed maintained its anti-inflation posture until mid1958, easing only when policymakers had become convinced that inflation was falling. M1 growth exceeded 6 percent during the final two quarters of 1958 after having fallen at about a 2 percent annual rate during the first half of that year. Monetary policy remained expansionary until late 1959 when a tighter policy caused M1 growth to fall. The economy entered yet another recession in the second quarter of 1960.

Even though inflation had remained low, slow

\footnotetext{
5 Stein (1969) notes that the Fed was supported in its policy by the Eisenhower administration and by many in the academic community.

6 The business cycle peaked in August 1957, and the downturn continued to April 1958. A common view at the time was that this recession was "only an interruption in the inflationary pressure, and the fact that it did not result in any decline of the price indexes was considered highly ominous" (Stein, 1969, p. 319)
}

economic growth and recurrent recessions-195354, 1957-58, and 1960-61-led to criticism of the Fed's policies. One group of economists - who were later labeled "monetarists" - blamed the Fed's "stopgo" policy actions, and resulting swings in money stock growth, for much of the instability in the macroeconomy. ${ }^{7}$ Other economists claimed that persistently tight monetary policy had contributed to the economy's tepid growth and high unemployment, though many considered monetary policy less effective than fiscal policy for stabilizing economic activity.

The principal economic advisors in the Kennedy administration were prominent Keynesians who favored the use of fiscal policy tools to stimulate rapid economic growth. ${ }^{8}$ In the Kennedy administration, writes Okun (1970, pp. 40-41), "the standard for judging economic performance [focused on] whether the economy was living up to its potential rather than merely whether it was advancing...As long as the economy was not realizing its potential, improvement was needed and government had a responsibility to promote it."

The Economic Report of the President for 1962 outlined the problem as Kennedy's advisors saw it: "Expectations in 1962 were colored by the suspicion that underutilization was to be the normal state of the American economy... [and] inadequate demand remains the clear and present danger to an improved economic performance" (1963, p. 23). The Report stated explicitly that "demands originating in the private economy are insufficient by themselves to carry us to full employment... [and] the Federal Government can relax its restraints on the expansionary powers of the private economy" by reducing taxes and reforming the tax system (1963, p. 32).

Where did monetary policy fit into this scheme? The consensus view, both outside and inside the Fed,

\footnotetext{
7 The FOMC focused on interest rates and free reserves (i.e., excess less borrowed reserves), not money stock growth, in its policy deliberations When the Fed desired a tighter policy, it would use open market operations to reduce (or limit the growth of) bank free reserves to increase the market yields on Treasury securities. Similarly, to ease monetary policy, the Fed would increase free reserves to reduce market yields. Friedman (1960) and Brunner and Meltzer (1964), among others, argued that this approach caused undesirable swings in money stock growth that interfered with the Fed's ability to achieve the broad policy objectives of price stability, low unemployment, and economic growth.

8 The belief that fiscal policy was a potent tool in economic stabilization was not confined to the White House. Fed Chairman Martin (1961, p. 279), testified to the Joint Economic Committee on March 7, 1961, that in the fight against inflation "undue reliance has perhaps been placed on monetary policy. I can readily agree with those who would have fiscal policy.... carry a greater responsibility for combating inflation."
} 
was that monetary policy should accommodate the needs of fiscal policy, which meant keeping interest rates low. Although nominally constrained by the continuing balance of payment deficits, monetary policy was generally consistent with the Kennedy administration's desires. Okun (1970, p. 55) writes that "the Fed did not 'lean against the wind' during 1961-65. As long as the economy continued to operate below its potential and prices remained stable, the Fed was prepared to provide the liquidity to sustain the advance." 9

Extended summaries of the FOMC Memoranda of Discussion corroborate Okun's view, although there probably was more concern expressed about a possible resurgence of inflation in FOMC deliberations than in White House meetings. For example, at an FOMC meeting on December 17, 1963, Federal Reserve Chairman Martin commented that the "whole western world was again faced with the specter of inflation... and he was opposed to inflation because it led to deflation. There were those who believed that unemployment could be cured by easy money. He doubted this... Budget, fiscal and wage-price policies had more fundamental effects" ( FOMC, December 17, 1963, p. 55-56). ${ }^{10}$

The Phillips curve was cemented firmly into the policy calculus of administration advisors and many Federal Reserve economists. ${ }^{11}$ Using this framework, the president's advisors estimated that if the economy were operating at its potential, the unemployment rate would be approximately 4 percent and the inflation rate would be about 2 percent. ${ }^{12}$ Fiscal and monetary policies were not

9 The March 26, 1963, FOMC meeting, which ended in agreement to not change course, produced a policy directive that is representative of the times: "This policy [to accommodate moderate growth in bank credit and minimize capital outflows] takes into account the continuing adverse United States balance of payments position and the increases in bank credit, money supply, and the reserve base in recent months, but at the same time recognizes the limited progress of the domestic economy, the continuing underutilization of resources, and the absence of general inflationary pressures" (FOMC, 1963, p. 47).

${ }^{10}$ The Memoranda of Discussion are not verbatim transcripts of FOMC meetings, but rather summaries of statements made by meeting participants.

11 Some administration advisors helped develop the Phillips curve for policy use. See, for example, Samuelson and Solow (1960). See Taylor (1997) for a discussion of how use of the Phillips curve led to an inflation bias in policy.

12 See Hetzel (1995) for additional detail. The impression one gets from interviews with former Fed officials is that the FOMC did not explicitly use the Phillips curve in its discussions. Still, the policy discussion available in the FOMC Memoranda of Discussion suggests that such a tradeoff was recognized and affected policy decisions. See Mayer (1995, 1999). considered adequately expansionary if the unemployment rate rose above 4 percent.

After declining steadily since 1961, full employment (i.e., a 4 percent unemployment rate) was achieved in 1965. Although many economists and policymakers recognized that expansionary policies could lead to higher inflation, consumer price inflation appeared to be contained. Wholesale prices, however, began to rise rapidly in 1965 . With federal budget deficits also expanding, fears of higher inflation were ignited. Nevertheless, by September 1965, Fed Chairman Martin opined that price pressures were not sustainable and that "it would be desirable to keep to the status quo, with the [Open Market] Desk maintaining market conditions on as even a keel as possible at this juncture" (FOMC, September 28,1965 , p. 94).

Martin's views changed quickly. Inflation became more apparent as 1965 was drawing to a close. Despite pressure from the White House, Martin and other Fed officials began to advocate a more restrictive policy. ${ }^{13}$ Martin stated at an FOMC meeting in late November that "if any Reserve Bank should come in with an increase in the discount rate he would be prepared to approve" (FOMC, November 23, 1965, p. 87). On December 6, 1965, the discount rate was increased from 4 to 4.5 percent. The Board of Governors was deeply divided over the increasefour members voted to approve the increase and three opposed. The Johnson administration and some members of Congress were publicly critical of the Fed's move, with some administration officials even questioning whether the Fed should have the power to act independently. ${ }^{14}$

Foreshadowing later episodes, the Fed's effort to contain inflation was short-lived. Monetary policy tightened further in mid-1966, but the Fed soon relented under pressure that intensified when interest-sensitive sectors of the economy began to show signs of weakness. By early 1967 monetary policy, as measured by the growth of monetary

\footnotetext{
${ }^{13}$ St. Louis Fed president Harry Shuford, Francis's predecessor, argued for monetary restraint at an FOMC meeting on November 2, 1965. He and a few others recognized that "The economy was operating near capacity, and at this time the rate of increase in spending appeared to be faster than the growth in ability to produce" (FOMC, 1965, p. 23). Fed Governor Charles Shepardson concurred, stating that "the rate of recent expansion was unsustainable, and at some point steps must be taken to try to dampen it" (FOMC, 1965, p. 34).

${ }^{14}$ For example, Gardner Ackley, Chairman of the Council of Economic Advisors, argued that "The Federal Reserve System is part of the government, and should be responsible to the administration" (cited in Hetzel, 1995, p. 19).
} 
aggregates, had once again become extremely expansionary. 15

\section{THE FRANCIS YEARS}

Darryl Francis became president of the Federal Reserve Bank of St. Louis in 1966. In the tradition of his predecessors, he was an outspoken critic of the Fed's monetary policies. ${ }^{16}$ Francis strongly supported the goal of halting inflation, but felt that the Fed's actions in late 1965 and early 1966 had been too timid. At an FOMC meeting on May 10, 1966, he noted that the monetary aggregates were continuing to grow rapidly, which he attributed to the Fed's reluctance to allow interest rates to rise. At the subsequent FOMC meeting on June 28, he pointed out that "while it was generally believed that interest rates had been rising in a restrictive manner during the past year, they had, in a very real sense, not done so. The cost of money to the borrower and the return to the saver were affected by changes in the value of the dollar. When one adjusted market interest rates for the decline in the value of the dollar [i.e., for inflation]... one found that interest costs had not risen at all in the past year...During the year market interest rate increases had provided no restriction to the excessive total demand" (FOMC, June 28, 1966, p. 65).

Measured by Francis's preferred gauge of monetary policy - the growth of monetary aggregatespolicy became considerably tighter as 1966 progressed. By autumn, Francis voiced concerns that monetary policy had become too tight: "Monetary developments since last spring had been restrictive... Member bank reserves had declined moderately, growth of bank credit had slowed markedly, and the money supply had changed little on balance... Care now had to be taken to avoid becoming too restrictive...Steps should be taken to avoid any sustained monetary contraction, as well as to avoid a renewal of the rapid monetary expansion that occurred last winter and spring" (FOMC, November 1 , 1966, pp. 78-79).

Francis's statements at FOMC meetings during his first year in office reflected fundamental views

\footnotetext{
${ }^{15}$ See Cagan (1972) for a detailed discussion of monetary policy during this period.

${ }^{16}$ Francis's predecessors at the St. Louis Bank, Delos Johns and Harry Shuford, also argued for the use of monetary aggregates in the conduct and description of policy. This tradition no doubt reflected the influence of Homer Jones, who was the director of research at the St. Louis Fed from 1958-71. Jones's influence is examined in a special volume of the Journal of Monetary Economics (1976).
}

about monetary policy that he shared with other monetarists. The quotes above, for example, illustrate his belief that the stance of monetary policy is measured appropriately by the growth rates of monetary aggregates, not the level of interest rates, and that the Fed should keep the money stock growing at a steady pace, rather than allow it to fluctuate widely. His calls for targeting the money stock growth rate and for focusing monetary policy exclusively on containing inflation, while gaining some support in academic circles, put him at odds with most of his Fed colleagues. In this section, we examine Francis's policy pronouncements in detail and how they challenged the prevailing consensus among Federal Reserve policymakers. ${ }^{17}$

\section{Monetary Policy and Employment}

Many of Francis's policy views would not be controversial today, but fell outside the mainstream during his tenure at the Fed. For example, a dominant view among macroeconomists at that time was that the government should respond to any shortfalls in employment or output growth. The Fed was widely accused of having been overly concerned with preventing inflation during the 1950s, which many economists claimed had kept the unemployment rate higher than necessary. ${ }^{18}$ Although reasonable stability of the price level was seen as desirable, many economists and policymakers argued that modest inflation was an acceptable cost of achieving high employment. Moreover, many claimed that any inflation that did occur when the economy was at less than full employment was due not to monetary policy but to "excessive" increases in wages or other costs.

Although widely held, the mainstream views about inflation and the role of monetary policy did not go unchallenged. Friedman (1968) and Phelps (1967) argued that the unemployment rate would tend toward a "natural rate" in the long run, irrespective of the rate of inflation. Friedman preached that "inflation is always and everywhere a monetary phenomenon" and argued that fluctuations in money stock growth historically had been a principal

\footnotetext{
${ }^{17}$ Although Francis's intellectual debt to his research staff and others should not be ignored, it was Francis who advocated these unpopular ideas and new research results in FOMC policy discussions and public venues.

${ }^{18}$ For example, see the views expressed by participants in a symposium on (then) recent monetary policy in the Review of Economics and Statistics (1960).
} 
cause of short-run fluctuations in real output and employment. By fixing money stock growth at the long-run growth rate of real output (adjusted for the trend growth of velocity), Friedman claimed that the price level would remain stable and monetary policy would not contribute to business cycle fluctuations. ${ }^{19}$

Francis shared many of Friedman's views and advocated them in policy discussions. Francis decried attempts to use monetary policy to control the unemployment rate, claiming that "Use [of monetary policy] as a short-run stabilizing tool produces costs in terms of lost employment and output and undesired price level movements" (1972, p. 34). Further, he argued, "I am convinced that future stabilization of our economy depends heavily upon a moderate and stable growth of the money stock. But if the pronouncements of critics of the monetarist view are heeded, the result will most likely be erratic fluctuations in the money stock caused by attempts to 'fine tune' the economy. Such fluctuations will necessarily cause periods of inflation and will be frequently accompanied by unacceptable levels of unemployment" (1972, p. 38). In Francis's view, "stop-go" monetary policy, by which he meant abrupt shifts from slow to rapid growth of the money stock, was an important cause of fluctuations in output growth and inflation: "Only by eliminating the stopgo stabilization actions...could [monetary] policy makers permanently improve the total social welfare and avoid acting as the architects of successive waves of intensifying inflation and recession" (FOMC, April 6, 1971, pp. 77-78).

Today, Francis might be described as an inflation "hawk" because he often argued that monetary growth was too fast and inflation too high. In the fall of 1966 and again in October 1969, however, Francis pressed for an easier monetary policy because he believed that monetary growth was too slow and the danger of recession was high. On the latter occasion he argued that "The studies made at his Bank indicated...that, if the System did not permit some growth in key monetary aggregates beginning now, an unacceptable economic recession would most likely develop in 1970, which in turn might force the Committee into [an] inordinate monetary expansion" (FOMC, October 28, 1969, pp. 54). ${ }^{20}$ Francis was prescient: The U.S. econ-

\footnotetext{
${ }^{19}$ See, for example, Friedman (1960) or Friedman and Schwartz (1963).

${ }^{20}$ Francis often cited and introduced into the record of FOMC meetings research results produced by his research staff. Of these, perhaps the most controversial was that of Andersen and Jordan (1968).
}

omy entered a recession in the fourth quarter of 1969.

Francis attributed the increasing trend rate of inflation that began in the mid-1960s to the Fed's persistent attempts to hold the unemployment rate below a level consistent with price stability. At the time, the consensus among most policymakers and economists was that a 4 percent unemployment rate represented full employment. In hindsight, it is now widely believed that the "natural rate" was really 5 percent or higher throughout the 1970s. ${ }^{21}$ Even though Francis probably had no more insight about the natural rate of unemployment than any other Fed policymaker, as early as 1970 he questioned whether a 4 percent rate of unemployment could be achieved without generating higher inflation: "When spending was rising fast enough to keep the unemployment rate at about 4 percent, strong upward pressure was exerted on prices and price expectations...Much of the current unemployment was structural and could not be obviated except temporarily and with adverse price effects by stimulation of total spending" (FOMC, August 18, 1970, pp. 44-45). In 1971 he again noted that "In the last decade whenever the unemployment rate had been below 5 percent inflation had accelerated, largely because of labor market imperfections" (FOMC, April 6, 1971, p. 30).

\section{The Cause or Causes of Inflation}

Friedman and other monetarists believed that the impact of monetary policy on real output and employment was transitory: Over time, monetary policy affected only the price level, while sustained movements in the price level were caused solely by growth of the money stock in excess of total output growth. At the time, however, many economists and policymakers attributed inflation to imperfections in labor or product markets, expansionary fiscal policy, shortages of raw materials, and other nonmonetary forces. Federal Reserve Chairman Arthur Burns, for example, blamed the inflation of the 1970s on increases in wages and other costs in excess of productivity gains. In a speech given in December 1970, Burns complained that "Governmental efforts to achieve price stability continue to be thwarted by the continuance of wage increases substantially

\footnotetext{
21 For example, the Economic Report of the President for 1977 recognized that productivity growth had slowed substantially in the late $1960 \mathrm{~s}$ and estimated that the "full employment rate of unemployment" was approximately 5.5 percent (1978, pp. 45-57).
} 
in excess of productivity gains... The inflation that we are still experiencing is no longer due to excess demand. It rests rather on the upward push of costs - mainly, sharply rising wage rates." He argued, moreover, that "Monetary and fiscal tools are inadequate for dealing with sources of price inflation such as are plaguing us now - that is pressures on costs arising from excessive wage increases" (Burns, 1978, pp. 112-13). ${ }^{22}$

Burns often made similar comments at FOMC meetings. For example, at a meeting on April 7, 1970, he suggested that "The inflation that was occurringand that was now being accentuated... was of the cost-push variety. That type of inflation...could not be dealt with successfully from the monetary side and it would be a great mistake to try to do so" (FOMC, April 7, 1970, p. 50). Whereas Burns viewed wage increases as the dominant cause of inflation during the 1970s, he blamed expansionary fiscal policy for the initial increase in inflation during the mid-1960s: "The current inflationary problem emerged in the middle 1960s when our government was pursuing a dangerously expansive fiscal policy ... Our underlying inflationary problem... stems in very large part from loose fiscal policy" (Burns, 1978, p. 177). ${ }^{23}$

Francis disagreed. Unlike some of his contemporaries on the FOMC, Francis did not confuse changes in relative prices with persistent increases in the general level of prices. While monetary policy could affect the latter, changes in relative prices were caused by market forces beyond the Fed's control. In a February 1972 speech, for example, Francis argued that "In the long run the growth of output and employment is determined by the growth of resources of a society... The trend growth of prices is determined by the trend growth of money stock relative to growth in output...Deviations from a trend rate of growth of money...cause short-run deviations in output and employment...But once the adjustment is completed, output and employment will resume their longer-run growth paths" (Francis, 1972, p. 33). In another speech, Francis noted that "other factors have an influence on the movement of prices in a given year. But when we talk about the 'problem of inflation,' I think it is safe to say that the fundamental cause is excessive

\footnotetext{
22 Burns made these statements in a speech titled "The Basis for Lasting Prosperity," given December 7, 1970.

23 Burns made this statement in a speech titled "Key Issues of Monetary Policy," given July 30, 1974
}

money growth" (Francis, 1974, pp. 6-7). ${ }^{24}$ As a policy issue, the distinction between changes in relative prices and inflation became even more important when petroleum prices increased sharply in 1973.

\section{The Cure for Inflation}

In light of their differing views about the cause of inflation, not surprisingly Burns and Francis disagreed about how to end inflation. By the late 1960s inflation clearly was on an upward trend. As Francis pointed out in early 1969, "For about four years... the [Federal Open Market] Committee had been led into unintended inflationary monetary expansion while following interest rate, net reserves, and bank credit objectives and the even keel constraint. He suggested that, if the Committee meant business now, it should try some other guides" (FOMC, February 4, 1969, p. 47). Specifically, Francis sought an operating procedure that focused on controlling the growth of money. His view, from which he did not waver during his ten years on the FOMC, was that "the cure [for inflation] is to slow down the rate of money expansion" (Francis, 1974, p. 7).

In contrast, Burns, other members of the FOMC, and administration economists promoted wage and price controls as the only viable policy for stopping inflation. "The persistence of rapid advances of wages and prices in the United States and other countries, even during periods of recession," Burns argued, "has led me to conclude that governmental power to restrain directly the advance of prices and money incomes constitutes a necessary addition to our arsenal of economic stabilization weapons" (Burns, 1978, p. 156). ${ }^{25}$ At an FOMC meeting on June 8, 1971, Burns argued that "Monetary policy could do very little to arrest an inflation that rested so heavily on wage-cost pressures...A much higher rate of unemployment produced by monetary policy would not moderate such pressures appreciably...He intended to continue to press [the administration]

\footnotetext{
24 Even though Burns later admitted that "Inflation cannot continue indefinitely without an accommodating increase in supplies of money and credit" (Burns, 1978, p. 208), he argued that inflation could continue well after monetary stimulus was removed, even during a period of rising unemployment: In 1971 he argued that "inflation caused by excess demand became entrenched, and remained after demand-side pressures abated. Entrenched inflation, increased militancy of labor, and willingness of business to accede to labor's wage demands, explains continued rising prices during periods of rising unemployment" (Burns, 1978, p. 126). Burns made this statement in a speech titled "The Economy in Mid-1971," given July 23, 1971.

25 Burns made this statement in a speech titled "Some Problems of Central Banking," given June 6, 1973.
} 
hard for an effective incomes policy" (FOMC, June 8, 1971, p. 51). On August 15 of that year, President Nixon unveiled his New Economic Program and introduced the first of three phases of direct wage and price controls.

Francis was highly critical of government controls on prices and wages, as they simply disrupted market signals. At an FOMC meeting in December 1967, he suggested that "Selective credit controls, wage freezes, and price restrictions had been advocated as alternatives [to contain inflation]. Such controls, however...raised problems of resource allocation; they interfered with freedom; and they were difficult to administer" (FOMC, December 12, 1967, pp. 54-55). In December 1970, Francis again argued at an FOMC meeting that "The adoption of administrative controls in attempting to hold down inflation, or to shorten the period of adjustment, would impose a great cost on the private enterprise economy. Serious inefficiencies would develop in the operations of the market system" (FOMC, December 15,1970, p. 74). While such controls might mask inflation for a time, "a freeze or other control programs could not be expected to effectively restrain inflation unless accompanied by sound monetary actions" (FOMC, October 19, 1971, p. 36). In Francis's view, low rates of inflation could not be achieved over the long run unless the money stock grew at a rate approximately equal to the long-run growth rate of real economic activity. Wage and price controls, to Francis, were merely impediments to the efficient working of a free market.

\section{Money Versus the Money Market}

The money stock did not grow at anything like the steady rate that Francis and other monetarists advocated. They attributed wide swings in money growth to the Fed's strategy of targeting market (i.e., nominal) interest rates. During World War II and for several years afterward, Federal Reserve open market operations were aimed primarily at maintaining low and stable yields on U.S. Treasury securities. The Federal Reserve-Treasury Accord of 1951 removed the Fed's obligation to maintain ceilings on Treasury security yields, but both yields and the general "condition" of the Treasury securities market remained important concerns of open market policy. In particular, the Fed typically would act to prevent market yields from changing whenever the Treasury issued new debt-a policy known as maintaining an "even keel."

The Fed used this "money market" strategy to implement policy throughout the 1950s, 1960s, and 1970s. Francis was highly critical of the approach because it detracted from his preferred policy of stable growth of the money stock. ${ }^{26}$ Moreover, he eschewed the use of market interest rates as a guide for policy because their movement did not always reflect policy actions. While rising interest rates often were considered a sign of monetary policy tightening, Francis noted that rising rates also could reflect rising inflation, the outcome of an expansionary monetary policy.

From the first FOMC meetings he attended, Francis chided the Committee for previous policies that, in his view, contributed to uncertainty over the stance of policy. For example, at a meeting on May 10, 1966, Francis observed that "There had now been ten or eleven months when the directive had continuously called for a moderation or restriction of expansion in bank reserves, bank credit, and money, and at the same time called for only slightly firmer money market conditions. Those instructions [have] been inconsistent... [and have led to] very rapid increases in bank reserves, bank credit and the money supply" (FOMC, May 10, 1966, p. 49). He expressed this view often during the late 1960 s, both at FOMC meetings and in public forums. Speaking to a group of financial market practitioners in New York City in 1968, Francis argued that "Measures of money market conditions such as market interest rates and free reserves have been shown to be poor indicators of the influence of monetary actions." And, "for stabilization purposes, movements in interest rates should be viewed no differently than movements in commodity prices" (Francis, 1968, p. 8).

The FOMC never abandoned money market conditions or interest rates as policy targets. In 1970, however, FOMC policy directives began to include specific targets for the growth of money and bank credit, as well as for money market conditions. Frequently the objectives for money and credit were in conflict with those specified for interest rates, and the latter were usually permitted to take precedence. Citing such conflicts, Francis voted against two policy directives in 1973 because he did not believe that the monetary growth rates specified in those directives - which he agreed with-would be

\footnotetext{
${ }^{26}$ Francis was not the first Federal Reserve Bank president to criticize the money market approach. The president of the Federal Reserve Bank of Atlanta, Malcolm Bryan, argued against the approach in the 1950s in favor of targeting a monetary aggregate (Meigs, 1976; Hafer, 1999).
} 
achieved given the money market objectives the directives also specified. ${ }^{27}$ The failure to achieve the monetary growth objectives set by the FOMC led Francis to argue for making public the FOMC's targets and its record of achieving those targets: "The records should contain a clearer description of the whole process of making and implementing policy, including information on targets that were missed and on those that were hit" (FOMC,

December 17, 1973, p. 14).

In contrast to Francis, most FOMC members were unwilling to discard interest rates or money market conditions as proximate objectives for monetary policy. Burns sometimes made statements at FOMC meetings favoring tighter control of the growth of monetary aggregates. He more frequently spoke against monetarist policy prescriptions, however, both at FOMC meetings and in public comments. For example, at an FOMC meeting in early 1971, Burns argued that "the heavy emphasis that many people were placing on the behavior of M1 involved an excessively simplified view of monetary policy" (FOMC, February 9, 1971, p. 87). And, in congressional testimony in 1975, he stated: "There is a school of thought that holds that the Federal Reserve need pay no attention to interest rates, that the only thing that matters is how this or that monetary aggregate is behaving. We at the Federal Reserve cannot afford the luxury of any such mechanical rule...We pay close attention to interest rates because of their profound effects on the working of the economy" (Burns, 1978, p. 369). ${ }^{28}$

\section{Supply Shocks}

Francis's policy views were shaped and supported by considerable empirical research conducted by St. Louis Fed staff, as well as economists outside the System. The St. Louis Fed formulated a simple, yet highly accurate forecasting model and began to publish forecasts in the Bank's Review in April 1970 (Andersen and Carlson, 1970). Like other models, however, the St. Louis model seriously under-forecast inflation in 1973-74 and the decline in real economic activity in 1974-75. Burns noted this in testimony before the House Committee on Banking and Currency in July 1974: "Inflationary tendencies

\footnotetext{
${ }^{27}$ See FOMC, July 17 and August 21, 1973.

${ }^{28}$ Burns made this statement in testimony titled "Monetary Targets and Credit Allocation" to the Subcommittee on Domestic Monetary Policy, U.S. House Banking, Currency, and Housing Committee, February 6, 1975.
}

and monetary expansion are not as closely related as is sometimes imagined. For example, the econometric model of the St. Louis Federal Reserve Bank, which assigns a major role to growth of the money stock in movements of the general price level, has seriously underestimated the rate of inflation since the beginning of 1973 ...Apparently, special factors... have been at work" (Burns, 1978, p. 176). ${ }^{29}$

Francis acknowledged that "With respect to inflation...the rise in prices in 1974 was just about double the increase that he would have expected to result from the policy actions that had been taken. Special factors, such as the energy and agricultural problems, had contributed to the rise in prices in 1974" (FOMC, December 17, 1974, p. 99). Francis reiterated his earlier position that observed changes in the price level caused by changes in relative prices associated with supply disturbances could not persist indefinitely. As he had argued almost a decade earlier, over time inflation was a monetary phenomenon. In a speech in October 1974, for example, he stated that he was "not willing to accept the special factor explanation of inflation because that explanation removes the focus from inflation as a monetary phenomenon" (Francis, 1974, p. 5).

In policy discussions, Francis warned against tightening excessively in response to a temporary increase in the price level caused by supply shocks, claiming that the special "factors would not continue to exert strong upward pressure [on inflation] in 1975 , and the rate of inflation would subside" (FOMC, December 17, 1974, p. 99). At the same time, however, he also warned against excessive easing in response to the ongoing recession because it too had been caused by the supply shocks and not a lack of demand. At an FOMC meeting in January 1974, he argued that "the actual and prospective slowdown in economic activity resulted wholly from capacity, supply, and price-distorting constraints and not from a weakening in demand. Therefore, to ease policy and allow a faster rate of monetary growth would be to increase inflationary pressures without expanding real output or reducing unemployment" (FOMC, January 22, 1974, p. 102). And, in December of that year, he argued that "The current decline in economic activity differed from past recessions in a number of respects. First, it was one of the few declines, if not the only one, to have developed without having been preceded by stabi-

\footnotetext{
${ }^{29}$ Burns made this statement in testimony titled "Key Issues of Monetary Policy," given July 30, 1974.
} 
lization policy actions that brought it about. Second, there had been an absolute decline in the country's capacity to produce, caused by the agricultural and energy problems, by the distortions resulting from the wage and price controls, by the new environmental and safety standards, and by changes in foreign exchange rates" (FOMC, December 17, 1974, p. 99). Rapid money stock growth, Francis argued, could do little to affect the growth of real output or employment in such a circumstance and would result mainly in a higher rate of inflation.

\section{CONCLUSION}

Darryl Francis served as president of the Federal Reserve Bank of St. Louis during tumultuous economic times. Even so, Francis's views about monetary policy reflected an underlying set of beliefs from which he did not waver. The "four basic premises" that guided him in his policy prescriptions were set out in an early speech and reprinted in the Federal Reserve Bank of St. Louis Review in 1968 (Francis, 1968). These premises are as follows: "First, a predominantly market orientation." Francis firmly believed in the unequaled efficiency of free markets to allocate incomes and goods and services. "Second, quantification is essential." In contrast to most of his FOMC colleagues, Francis consistently fought for quantifiable policy rules and measures of the success or failure of policy actions. "Third, our economic system is more stable than was believed a few years ago." Francis believed that, over time, real economic growth was determined by population growth, capital formation, and technology. Monetary policy, in his view, could not reliably improve on market outcomes in the short run, or increase real output growth (or lower the unemployment rate) in the long run. Although not the accepted wisdom in his time, such a view today is fundamental.

"Fourth, monetary management is more properly directed toward influencing changes in total spending." Francis questioned attempts to use monetary or fiscal policies to affect specific markets or sectors of the economy. Although actions taken to achieve price stability could impinge more on some sectors than on others, Francis argued that free markets would adjust to such actions. Allocation of goods and services or resources by market forces, he believed, was preferable to allocation by government decree.

Francis did not think about monetary policy in terms of forward-looking, dynamic rules or deep theoretical models. He had strong convictions about the efficacy of market forces and the limitations of government stabilization policies. Even though Francis believed that monetary policy could exert a powerful short-run impact on the unemployment rate, he was convinced that it could not be used to permanently steer the economy to any particular rate of growth. In the long run, Francis believed that monetary policy affected only the price level. Maintaining price stability, Francis believed, would help establish conditions that would foster maximum employment and economic growth. Although not widely shared among his contemporary Federal Reserve colleagues, today such views are mainstream.

\section{REFERENCES}

Andersen, Leonall and Jordan, Jerry L. "Monetary and Fiscal Actions: A Test of Their Importance in Economic Stabilization." Federal Reserve Bank of St. Louis Review, November 1968, 50(11), pp. 11-24.

and Carlson, Keith M. "A Monetarist Model for Economic Stabilization.” Federal Reserve Bank of St. Louis Review, April 1970, 52(4), pp. 7-25.

Barsky, Robert B. and Kilian, Lutz. "Do We Really Know That Oil Caused the Great Stagflation? A Monetary Alternative." NBER Working Paper No. 8389, National Bureau of Economic Research, July 2001.

Brunner, Karl and Meltzer, Allan H. The Federal Reserve's Attachment to the Free Reserve Concept. Washington, DC: House Committee on Banking and Currency, 1964.

Burns, Arthur F. Reflections of an Economic Policy Maker: Speeches and Congressional Statements: 1969-1978. Washington, DC: American Enterprise Institute for Public Policy Research, 1978.

Cagan, Phillip. "Monetary Policy," in Phillip Cagan et al., eds., Economic Policy and Inflation in the Sixties. Washington, DC: American Enterprise Institute for Public Policy Research, 1972, pp. 89-154.

Economic Report of the President (various years).

Federal Open Market Committee. Memoranda of Discussion (various dates).

Francis, Darryl R. "An Approach to Monetary and Fiscal Management.” Federal Reserve Bank of St. Louis Review, November 1968, 50(11), pp. 6-10. 
"Has Monetarism Failed?-The Record Examined.” Federal Reserve Bank of St. Louis Review, March 1972, 54(3), pp. 32-38.

"Inflation, Recession-What's a Policymaker

To Do?" Federal Reserve Bank of St. Louis Review, November 1974, 56(11), pp. 3-7.

Friedman, Milton. "The Role of Monetary Policy." American Economic Review, March 1968, 58(1), pp. 1-17.

A Program for Monetary Stability. New York: Fordham University Press, 1960.

and Schwartz, Anna Jacobson. A Monetary

History of the United States: 1867-1960. Princeton: Princeton University Press, 1963.

Hafer, R.W. "Against the Tide: Malcolm Bryan and the Introduction of Monetary Aggregate Targets." Federal Reserve Bank of Atlanta Economic Review, First Quarter 1999, 84(1), pp. 20-37.

and Wheelock, David C. "The Rise and Fall of a Policy Rule: Monetarism at the St. Louis Fed, 1968-1986." Federal Reserve Bank of St. Louis Review, January/February 2001, 83(1), pp. 1-24.

Hetzel, Robert L. "William McChesney Martin and Monetary Policy in the 1960s." Unpublished manuscript, Federal Reserve Bank of Richmond, April 1995.

Jordan, Jerry. "Darryl Francis: Maverick in the Formulation of Monetary Policy." Federal Reserve Bank of St. Louis Review, July/August 2001, 83(4), pp. 17-22.

Journal of Monetary Economics. "Contributions in Honor of Homer Jones.” November 1976, 2(4), pp. 431-71.

Martin, William McChesney Jr. "Federal Reserve Operations in Perspective." Federal Reserve Bulletin, March 1961, 47(3), pp. 272-81.

Mayer, Thomas. Interviews, special collections, general library, University of California-Davis, 1995.
Monetary Policy and the Great Inflation in the United States: The Federal Reserve and the Failure of Macroeconomic Policy, 1965-79. Cheltenham, UK: Elgar, 1999.

Meigs, A. James. "Campaigning for Monetary Reform: The Federal Reserve Bank of St. Louis in 1959 and 1960.” Journal of Monetary Economics, November 1976, 2(4), pp. $439-53$.

Okun, Arthur M. The Political Economy of Prosperity. Washington, DC: The Brookings Institution, 1970.

Phelps, Edmund S. "Phillips Curves, Expectations of Inflation and Optimal Unemployment Over Time." Economica, August 1967, 34(135), pp. 254-81.

Poole, William. "Eulogy for Darryl R. Francis, 1912-2002." Federal Reserve Bank of St. Louis Review, March/April 2002, 84(2), pp. 1-2.

"President's Message." Federal Reserve Bank

of St. Louis Review, July/August 2001, 83(4), pp. 5-6.

Review of Economics and Statistics. "Controversial Issues in Recent Monetary Policy: A Symposium.” August 1960, 42(3), pp. 245-82.

Samuelson, Paul A. and Solow, Robert M. "Problems of Achieving and Maintaining a Stable Price Level: Analytical Aspects of Anti-Inflation Policy." American Economic Review, Papers and Proceedings, May 1960, 50(2), pp. 177-94.

Stein, Herbert. The Fiscal Revolution in America. Chicago: University of Chicago Press, 1969.

Taylor, John B. “America's Peacetime Inflation: The 1970s: Comment," in Christina D. Romer and David H. Romer, eds., Reducing Inflation: Motivation and Strategy. Chicago: University of Chicago Press, 1997, pp. 276-80. 